\title{
Contribution of Self Control and Peer Conformity to Consumptive Behavior
}

\author{
Amal Hayati ${ }^{1}$, A.Muri Yusuf ${ }^{2}$, Megaiswari Biran Asnah $^{3}$ \\ ${ }^{123}$ Guidance and Counseling of Padang State University \\ *Corresponding author, e-mail: amalhayatimrp@gmail.com
}

\begin{abstract}
The occurrence of consumptive behavior among adolescents is caused by several internal factors such as self-control, talents, interests, values, selfconcepts and knowledge and learning outcomes. External factors such as social class, family, culture, peers, and situations. Psychological factors such as information processing and learning. This study aims to describe the contribution of self-control and peer conformity to the consumptive behavior of students in Kisaran Private IT High Schools. The research method uses a quantitative approach with descriptive correlational type and multiple regression. The population of this study was 57 high school IT private high school students in class $X$ and the sample of 50 students were selected using proportional random sampling. The research findings show that: (1) on average, self-control is in the very high category, (2) peer conformity is also in the very high category, (3) consumer consumptive behavior is categorized very well, (4) there are $51 \%$ contribution of self-control to consumptive behavior, (5) there are $34 \%$ contribution of peer conformity to consumptive behavior, and (6) there are $60 \%$ contribution together with self-control and peer conformity towards consumptive behavior.
\end{abstract}

Keywords: Self-Control, Peer Conformity, Consumptive Behavior

How to Cite: Hayati, A., Yusuf, A. M., Asnah, M., B. (2020). Contribution of Self Control and Peer Conformity to Consumptive Behavior. International Journal of Applied Counseling and Social Sciences. 2 (1): pp. 16-24, DOI: 10.24036/005344ijaccs

This is an open access article distributed under the Creative Commons 4.0 Attribution License, which permits unrestricted use, distribution, and reproduction in any medium, provided the original work is properly cited. $@ 2020$ by Author

\section{Introduction}

High school students are part of teenagers. Adolescence is a transition period in the span of human life, connecting childhood and adulthood. In western countries, the term adolescence is known as "adolescence" which comes from the Latin word "adolescere" (the word adolescentia = adolescent), which means growing into adulthood or in development into adulthood. In the process of adjustment to maturity, there are three stages of adolescence namely, middle adolescence (early adolescence), middle adolescence (middle 
adolescence), late adolescence (late adolescence)(Azizah \& Listiara, 2017). The middle adolescent is the middle age range of 15-18 years. Whereas adolescents themselves are where the transition from childhood to preparation for adulthood, which at that time the emotional turmoil that makes teens attacked by by storm and stress. Teenagers range from 12-21 years(Desmita, 2007).

Shopping activities are considered as a job, socialactivity and one day become a competition for yourself (decide to buy or not) also especially for competition among friends and other members of the community (as a symbol of status, prestige, and human image)(Triyaningsih, 2011). This behavior is the behavior of consuming goods and services excessively, which is no longer based on rational considerations and is more concerned with the desire factor rather than the need only to achieve maximum satisfaction and pleasure that leads to waste(Ilham, 2017). At this time the concept of shopping as a reflection of lifestyle and recreation among the people. A variety of products are offered to consumers (Haryani \& Herwanto,2015).

The consumptive lifestyle encourages someone to want something instantly and quickly (Imawati, Susilaningsih \& Elvia, 2013).More specifically explained that this behavior is the desire to consume goods that are less needed in excess to achieve maximum satisfaction (Tambunan, 2001).

Society can not be separated from the influence of this consumption, so it is not strange if adolescents become targets of various company products. The fact that is often found is the tendency among young Indonesians to imitate the luxurious lifestyle, and the behavior that is happening in developed countries(Lina dan Haryanto, 1997).

Teenagers tend to buy a product not based on actual needs but only based on the desire to look good, to maintain prestige and self-esteem (Sahrah, 2014).One of the reasons why teenagers are more consumptive is that one of them is influenced by digital culture and internet usage(APJII, 2018). The millennial generation is the biggest shopper in the ecommerce field (Tashandra, 2018).

Teenagers are usually easily persuaded by advertisement seduction, like to go along with friends, are unrealistic, and tend to be wasteful in using their money. These adolescent qualities are used by some producers to enter the youth market(Fitriyani, Widodo, \& Fauziah, 2013).

Nowadays, the use of smartphones and easy internet access makes teenagers love online shopping activities because they don't need to leave home. The increase in people's purchasing power is a great opportunity for producers to market their consumers' needs in an online shopping application that can be accessed anytime and anywhere. The number of internet users who shop online in the country is said to have reached 24.74 million people. Over the past year, the users have spent the US \$ 5.6 billion (around Rp74.6 trillion) to shop at various e-commerce sites. From these data, it can be concluded that the average ecommerce user in the country spends around The US \$ 228 (around Rp. 3 million) per year (Rudiantara \& Rusli, 2017).

The results of a 2014 survey conducted by Tokopedia, which showed women constituted the majority dominated the number of purchases, the number of sales, the amount of expenditure, and the amount of income in Tokopedia. The average of goods spent consists of beauty and health products, clothing, fashion, accessories, and gadgets. The level of consumption based on the results of a survey conducted by Tokopedia has placed the 
majority of women with $66.28 \%$ as a consumptive society with spending duration that can reach 3 times a week (Tokopedia).

Consumptive behavior is influenced by various factors. Internal factors, namely; (1) Personality, lifestyle, and demographics, (2) Talents, interests, values, self-concepts \& (3) Knowledge and learning outcomes. External Factors namely; (1) Social class, (2) Family, (3) Culture, (4) influence of groups and reference groups, \& (5) Situation. Psychological Factors namely; (1) Information processing, (2) Learning and behavior change (Engel., Blackwell, \& Miniard, 1992). The buying behavior of a teenager is more likely to be impulsive (Sahrah, 2014). Ages 16-21 years tend to spend more time with their peers, trying to be accepted by the group by adjusting to the norms and climate in the group or conforming to peers who tend to behave mischievously (Saputro \& Soeharto, 2012).

Peer groups become very meaningful and influential in the social life of adolescents because they become a place to learn social skills and take on various roles (Saputro \& Soeharto, 2012). Teenagers need a container as a way to interact with their peers. The purpose of adolescents looking for a place is to establish a loyal friend who is close and bound by the same interests, common interests, mutual help and sharing feelings to solve problems together(Sarmin, 2017).

There is an oddity in adolescents who should be able to be independent and do not have their income, but because of an influence from the group, they tend to follow what is done by the group, as in the case of dressing. Teenagers who do not have an income can buy clothes through an online shop (Pertiwi, 2013).

The reason teens are more likely to conform to that teenagers need friends who can be trusted as a source of emotional support. These emotional support needs make teenagers willing to do something by their peers so as not to lose their emotional support(Sartika, Indrawati, \& Sawitri, 2009).

Most teenagers are now consumptive because of the contribution of high peer conformity. So teens can buy every fashion product they want and need. This is done so that teenagers can be accepted into a group, without thinking about the usefulness of each product. The number of online marketing activities carried out by producers who provide various fashion products for teenagers alsoencourages teens to behave in a consumptive manner (Triyaningsih, 2011). Many adolescents assume that if they look and behave in line with members of popular groups, the chances of being accepted in these popular groups are greater(Myers, 2012).

Late adolescents who have a developmental task are to strengthen self-control on the basis of the scale of values, principles or philosophy of life Adolescents can be said to have strengthened self control if they do not vent their emotions in front of others, but rather wait for a more appropriate time and place to express their emotions in acceptable ways. At that age, they need recognition from their social environment, still in the stage of searching for identity, and still in an unstable emotional state. The situation tends to make self-control weak so that any decisions made including buying decisions are dominated by momentary emotions (Anggreini \& Mariyanti, 2014).

Every individual has a mechanism that can help regulate behavior, especially students. They must be able to respond to the growing consumer consumptive power. This means that they are required to be able to control so that their passions and behavior can be overcome (Haryani \& Herwanto,2015). 
Self-control refers to the ability of someone to do something they want to do without being obstructed by obstacles or strengths that come from within the individual (Thalib, 2010).

Good self-control will be able to make priority considerations in buying, choose between the important and not important before deciding to buy. Conversely, those who have weak self-control will buy an item without considering its priorities (Anggreini \& Mariyanti, 2014).

The phenomenonin the field shows that students tend to want to be accepted into a group so they are very consumptive. This becomes the basis for students to have a consumptive attitude so that their presence in school is considered. They will do many ways to be accepted into the group, for example by following the group's daily life to come to buy every item purchased by group members. Students also have not been able to control themselves when doing shopping activities, especially when buying clothes that have many colors. This happens because of a lack of self-control to be frugal and the influence of peers that appearance is the main display so that students are considered worthy of being in the group, which makes students consumptive to constantly buy new products.

Students buy the same fashion products and items as their friends or even compare their possessions with those of their friends to see who is more trendy. Especially in the latest gadgets and smartphones. This happens to students who have groups in school, they will compare goods and products which groups are betterso that the group is considered the group most respected by other students. So that other students are interested and want to be included in the group so they can be considered as friends at the school.

The explanation explained that teenagers are very intense in conducting shopping activities both online and directly visiting the store. These problems occur because of the influence of peers and the difficulty of students in controlling themselves.

Seeing consumptive behavior that occurs among adolescents, especially in high school students raises various negative impacts rather than the positive The negative impact of consumptive lifestyle behavior occurs in someone who does not have a balance between income and expenditure (wasteful), in this case, the behavior had caused economic problems in his family(Hidayah, 2015).In this case, the biggest impact that occurs is this behavior will become a habit that can't be stopped to maintain self-esteem and the perspective of others towards him.

\section{Method}

The research method uses a quantitative approach with descriptive correlational type and multiple regression. The population of this research is the students of class $\mathrm{X}$ high school IT Private Range, amounting to 57 people, the research sample of 50 people were selected by proportional random sampling techniqueThe instrument used to collect data in this study was a questionnaire. Data were analyzed with descriptive statistics, simple and multiple regressions. Data analysis was assisted using the SPSS 20.0 program.

\section{Results and Discussion}

\section{Results}

Data in this study include self-control variables (X1), peer conformity (X2), consumptive behavior $(\mathrm{Y})$. The following is the research result data. 
Table 1. Frequency Distribution and Percentage Self-Control

\begin{tabular}{|c|c|c|c|}
\hline $\begin{array}{c}\text { Score } \\
\text { Interval }\end{array}$ & Category & Frequency & $\%$ \\
\hline$\geq 108$ & Very high & 34 & 68 \\
\hline $85-107$ & High & 16 & 32 \\
\hline $62-84$ & Is & 0 & 0 \\
\hline $39-61$ & Low & 0 & 0 \\
\hline$\leq 48$ & Very Low & 0 & 0 \\
\hline & Total & 50 & 100 \\
\hline
\end{tabular}

The table above shows that most students have very high self-control at $68 \%$, some students are in the high category at $32 \%$. On average students' self-control is in the very high category.

Table 2. Frequency Distribution and Percentage Peer Conformity

\begin{tabular}{|c|c|c|c|}
\hline $\begin{array}{c}\text { Score } \\
\text { Interval }\end{array}$ & Category & Frequency & \% \\
\hline$\geq 92$ & Very high & 27 & 54 \\
\hline $74-91$ & High & 23 & 46 \\
\hline $56-73$ & Is & 0 & 0 \\
\hline $38-57$ & Low & 0 & 0 \\
\hline$\leq 39$ & Very Low & 0 & 0 \\
\hline \multicolumn{2}{|c|}{ Total } & 50 & 100 \\
\hline
\end{tabular}

The table above shows that the conformity of students' peers is very high at $54 \%$, some students are in the high category that is $46 \%$. On average the peer conformity of students is in the very high category.

Table 3. Frequency Distribution and Percentage

\begin{tabular}{|c|c|c|c|}
\hline \multicolumn{4}{|c|}{ Consumptive Behavior } \\
\hline $\begin{array}{c}\text { Score } \\
\text { Interval }\end{array}$ & Category & Frequency & $\%$ \\
\hline$\geq 180$ & Very high & 33 & 66 \\
\hline $170-199$ & High & 17 & 34 \\
\hline $142-171$ & Is & 0 & 0 \\
\hline 114-143 & Low & 0 & 0 \\
\hline$\leq 115$ & Very Low & 0 & 0 \\
\hline & Total & 50 & 100 \\
\hline
\end{tabular}

The table above shows that the majority of students have very high consumptive behavior at $66 \%$, some students are in the high category at $34 \%$. On average it has a consumptive behavior of students in the very high category. 


\section{Contribution of Self Control and Peer Conformity to Student Consumptive Behavior Table 4. Results of Analysis of the Contribution of Self Control (X1) on Student Consumptive Behavior (Y)

\begin{tabular}{|c|c|c|c|}
\hline Model & R & R Square & Sig. \\
\hline $\mathrm{X} 1-\mathrm{Y}$ & 0.718 & 0.516 & 0.000 \\
\hline
\end{tabular}

In table 5. it can be seen that the R-value of 0.587 which shows the correlation of peer conformity with consumptive behavior with a significant level of 0,000. R Square (R2) value of 0.344 means that $34 \%$ of the variation of consumptive behavior is explained by peer conformity, while the remaining $66 \%$ can be explained by other variables.

\section{Table 6. Results of Analysis of the Contribution of Self Control and Peer Conformity (X2) on Student Consumptive Behavior ( $Y$ )

\begin{tabular}{|l|c|c|c|}
\hline Model & $\mathbf{R}$ & R Square & Sig. \\
\hline $\mathrm{X} 1, \mathrm{X} 2-\mathrm{Y}$ & 0.777 & 0.604 & 0.000 \\
\hline
\end{tabular}

In table 6 . it can be seen that the R-value of 0.777 which shows the multiple regression coefficients between self-control and peer conformity to consumptive behavior with a significant level of 0,000 . R Square (R2) value of 0.604 means that $60 \%$ of the variation of consumptive behavior can be explained together with my self-control and peer conformity, while the remaining $40 \%$ can be explained by other variables not examined in this study.

\section{Discussion}

Self-control at Kisaran IT Private High Schools falls into 2 categories, namely very high and high. The results of data analysis show that on average the overall self-control of students can influence consumer behavior.

Students with good self-control skills will be able to regulate behavior using their abilities and if they are unable, students will use external sources. Students who can control their behavior by preventing or moving away from the stimulus, stop the stimulus before the time is over, and limit its intensity(Anggreini \& Mariyanti, 2014).

Individuals who have high self-control pay close attention to appropriate ways to behave in various situations. Individuals will tend to change their behavior by the demands of social situations which can then regulate the impression made. His behavior is more responsive to situational cues, more flexible, trying to facilitate social interaction, being warm and open(Haryani \& Herwanto, 2015)

Failure of students to control themselves well can result in students engaging in consumptive behavior. Consumptive behavior is marked by the habit of students not being able to regulate their desires in every purchase.

Peer conformity in Kisaran IT Private High Schools falls into 2 categories, namely very high and high categories. The results of the analysis of research data indicate that on average the overall conformity of student peers is in the very high category. The desire to be accepted and afraid of being ostracized encourages students to try to be the same as their classmates. Such encouragement not only comes from within oneself but also comes from outside self usually comes in the form of group pressures or pressure from other group members (Fitriyani, Widodo, \& Fauziah, 2013). 
With so many group demands to follow their norms, it makes a person behaves in a consumptive manner to be accepted as a group member. Efforts to minimize this conformity can be reduced by doing conformity on negative things, especially in terms of consuming an item that can make someone wasteful (Pratama, 2017)

Consumptive behavior in Kisaran IT Private High Schools is in 2 categories, namely very high and high categories. The results of the analysis of research data indicate that on average the overall conformity of student peers is in the very high category. Even though students can control themselves, they are suspected of shopping because they join their groups so they can be accepted into the group.

Human tendency to consume unlimited, no less often humans are concerned with emotional factors than the rational factors or more concerned with desires rather than needs. Everyone has a mechanism that can help regulate behavior, especially students. They must be able to respond to a growing consumerist culture. This means that they are required to be able to put the brakes on so that their passions and behavior can be overcome. So that consumer behavior that has mushroomed among students can now be minimized(Haryani \& Herwanto,2015)

The results showed that self-control significantly contributed to students' consumptive behavior. This finding was obtained based on data analysis that the contribution of selfcontrol to students' consumptive behavior was $51 \%$, while the rest $(49 \%)$ could be explained by other variables. That is, self-control is one of the factors that contribute to student consumptive behavior.

Based on these results, consumptive behavior is determined by self-control in controlling themselves in shopping activities and can refrain from any situation.

The results showed that self-control and peer conformity together contributed significantly to students' consumptive behavior. This finding was obtained based on data analysis that the contribution of peer conformity to the consumptive behavior of students was $34 \%$, while the rest $(66 \%)$ could be explained by other variables. That is, peer conformity is one of the factors that contribute to student consumptive behavior.

Students need a place for friends to build relationships in relationships. Conformity given by peers is not always positive, and therefore when the conformity given by peers is negative, it is difficult for students not to behave consumptively for the sake of their acceptance in the group.

The results showed that peer conformity significantly contributed to student consumptive behavior. This finding was obtained based on data analysis that the value of $R$ Square (R2) of 0.604 means that $60 \%$ of the variation of consumptive behavior can be explained jointly by self-control and peer conformity, while the remaining $40 \%$ can be explained by other variables.

Based on the above findings, it can be seen that self-control and peer conformity are factors that influence the consumptive behavior of students. Self-control is useful for selfcontrol when faced with circumstances that trigger excessive buying reactions so that in the end students who have good self-control will be easier to not have consumptive behavior. Likewise, peer conformity makes it easy for students not to follow their peers so as not to create consumptive behavior. 


\section{Conclusion}

Based on the results of the study it can be concluded that, on average, students' selfcontrol is in the very high category, student peer conformity is in the very high category, consumer consumptive behavior is in the very good category. Furthermore, self-control contributes significantly to the consumptive behavior of students by $51 \%$, peer conformity contributes significantly to student consumptive behavior by $34 \%$, self-control and peer conformity together contribute to the consumptive behavior of high school students IT Private $60 \%$ range. This means that both the level of consumptive behavior of students is not only influenced by one variable (self-control and peer conformity)but is influenced jointly by self-control and peer conformity. In other words, the higher the student's self-control and the lower the peer conformity, the better the consumptive behavior of students. This means that the variables of self-control and peer conformity are more effective when combined as a predictor to reduce student consumptive behavior rather than just one variable. The results of this study must also be of concern to school principals and students parents.

\section{References}

Anggreini, R., \& Mariyanti, S. (2014). Hubungan antara kontrol diri dan perilaku konsumtif mahasiswi Universitas Esa Unggul. Jurnal Psikologi, 12(1).

APJII. (2018). Infografis penetrasi \& perilaku pengguna internet Indonesia.

Desmita. (2007). Psikologi Perkembangan. Bandung: PT. Remaja Rosdalarya.

Engel, F. J., Blackwell, R.D. \& Miniard, P. W. (1992). Consumen BehaviorJilid I. The dryden Press.

Fitriyani, N., Widodo, P. B., \& Fauziah, N. (2013). Hubungan antara konformitas dengan perilaku konsumtif pada mahasiswa di genuk indah semarang. Jurnal Psikologi Undip, 12(I), 55-68.

Hidayah, R. W. (2015). Perilaku konsumtif dalam membeli produk fashion pada mahasiswa putri di Surakarta.Naskah Publikasi. Universitas Muhammadiyah Surakarta.

Ilham, F. (2017). Peranan sikap do it yourself (DIY) dalam meminimalisir perilaku konsumtif di kalangan remaja (studi kasus di Desa Banjaran Kabupaten Bandung). FKIP Unpas.

Imawati, I. \& S. \& I. (2013). Pengaruh financial literacy terhadap perilaku konsumtif remaja pada Program IPS SMA Negeri 1 Surakarta Tahun Ajaran 2012/2013. Jupe UNS, 2 No.1(1), 48-58. https://doi.org/10.1017/CBO9781107415324.004

Indah Haryani, \& Jhon Herwanto. (2015). Hubungan konformitas dan kontrol diri dengan perilaku konsumtif terhadap produk kosmetik pada mahasiswi. Jurnal Psikologi UIN Sultan Syarif Kasim Riau, 11(Juni), 5-11.

Lina dan Haryanto, F. R. (1997). Perilaku konsumtif berdasar locus of control pada remaja putri.Psikologika, 4(II), 5-13.

Myers, D. (2012). Social Psychology (11th ed.). McGraw-Hill Companies. 
N.P, Azizah \& A, L. (2017). Hubungan antara konformitas dengan perilaku konsumtif dalam pembelian tas melalui online shop pada mahasiswa Fakultas Ilmu Sosial dan Ilmu Politik (FISIP) dan Fakultas Ilmu Budaya (FIB) Universitas Dipenogoro. Universitas Dipenogoro, 6(1), 332-337.

pertiwi, d. r. (2013). Hubungan antara konformitas terhadap teman sebaya dengan perilaku konsumtif dalam membeli pakaian di online shop pada remaja SMA Kesatrian 1 Semarang. Universitas Diponegoro.

Pratama, H. S. (2017). Hubungan konformitas dengan perilaku konsumtif terhadap merchandise Liverpool pada anggota supporter klub sepakbola Liverpool di Bekasi. Jurnal Psikologi, 10(2).

Rudiantara \& Rusli, A. (2017). On the spotlight: Sosial media Indonesia. Jakarta.

Sahrah, A. R. dan A. A. (2014). Hubungan antara konformitas dengan perilaku membeli impulsif pada remaja putri. Universitas Wangsa Manggala Yogyakarta.

Sarmin. (2017). Konselor sebaya: pemberdayaan teman sebaya dalam sekolah guna menanggulangi pengaruh negatif lingkungan. Jurnal Unublitar, 2, 102-112.

Sartika, A. A., Indrawati, E. S., \& Sawitri, D. R. (2009). Hubungan antara konformitas terhadap teman sebaya dengan intensi merokok pada remaja perempuan di SMA Kesatrian 1 Semarang. Psycho idea, 7(I), 14-25.

Soeharto, B. M. S. \& T. N. E. D. (2012). Hubungan antara konformitas terhadap teman sebaya dengan kecenderungan kenakalan pada remaja. INSIGHT, 10(I), 1-15.

Tambunan. (2001). Remaja dan pola hidup konsumtif. Jurnal Psikologi.(Online)

Tashandra, N. (2018). 80 Persen konsumen belanja online orang muda dan wanita.(Online)

Thalib, S. B. (2010). Psikologi pendidikan berbasis analisis empiris aplikatif. Jakarta: Kencana.

Triyaningsih, S. . (2011). Dampak online marketing melalui facebook terhadap perilaku konsumtif masyarakat. Jurnal Ekonomi dan Kewirausahaan, 11(2), 172-177. 